\title{
Facets of career agility as explanatory mechanisms of employees' career adaptability
}

\begin{tabular}{|c|c|}
\hline $\begin{array}{l}\text { Authors: } \\
\text { Melinde Coet } \\
\text { Marais S. Best } \\
\text { Nadia Ferreira } \\
\text { Ingrid L. Potgi }\end{array}$ & $\begin{array}{l}\operatorname{ee}^{1}(\mathbb{D}) \\
r^{1}(1) \\
\operatorname{ter}^{2} \text { (1) }\end{array}$ \\
\hline $\begin{array}{l}\text { Affiliations: } \\
{ }^{1} \text { Department } \\
\text { and Organisat } \\
\text { Psychology, Ur } \\
\text { South Africa, } \\
\text { South Africa }\end{array}$ & $\begin{array}{l}\text { f Industrial } \\
\text { onal } \\
\text { iversity of } \\
\text { retoria, }\end{array}$ \\
\hline $\begin{array}{l}{ }^{2} \text { Department } \\
\text { Resource Man } \\
\text { University of S } \\
\text { Pretoria, Soutl }\end{array}$ & $\begin{array}{l}\text { f Human } \\
\text { agement, } \\
\text { outh Africa, } \\
\text { Africa }\end{array}$ \\
\hline $\begin{array}{l}\text { Correspondin } \\
\text { Melinde Coetz } \\
\text { coetzm1@uni }\end{array}$ & $\begin{array}{l}\text { author: } \\
\text { ee, } \\
\text { a.ac.za }\end{array}$ \\
\hline $\begin{array}{l}\text { Dates: } \\
\text { Received: } 20 \mathrm{~F} \\
\text { Accepted: } 16 \\
\text { Published: } 28\end{array}$ & $\begin{array}{l}\text { b. } 2020 \\
\text { pr. } 2020 \\
\text { Иay } 2020\end{array}$ \\
\hline $\begin{array}{l}\text { How to cite th } \\
\text { Coetzee, M., B } \\
\text { Ferreira, .N., \& } \\
\text { (2020). Facets } \\
\text { agility as expla } \\
\text { mechanisms o } \\
\text { career adaptal } \\
\text { Journal of Car } \\
\text { Development, } \\
\text { https://doi.org } \\
\text { v2i1.11 }\end{array}$ & $\begin{array}{l}\text { is article: } \\
\text { ester, M.S., } \\
\text { Potgieter, H. } \\
\text { of career } \\
\text { natory } \\
\text { employees' } \\
\text { ility. African } \\
\text { er } \\
2(1) \text {, a11. } \\
\text { /10.4102/ajcd. }\end{array}$ \\
\hline $\begin{array}{l}\text { Copyright: } \\
\text { (C) 2020. The A } \\
\text { Licensee: AOS } \\
\text { is licensed unc } \\
\text { Creative Comn } \\
\text { Attribution Lic }\end{array}$ & $\begin{array}{l}\text { uthors. } \\
\text { S. This work } \\
\text { er the } \\
\text { ions } \\
\text { ense. }\end{array}$ \\
\hline Read online: & \\
\hline 口idra & $\begin{array}{l}\text { Scan this QR } \\
\text { code with your } \\
\text { smart phone or } \\
\text { mobile device } \\
\text { to read online. }\end{array}$ \\
\hline
\end{tabular}

Background: The fast-changing Industry 4.0 employment conditions require employees to be highly adaptable and resilient in their career self-management. More insight is needed regarding the manner in which facets of career agility (as indicators of adaptive readiness) explain the activation of career adaptability (as an indicator of self-regulated career management resources that help employees proactively respond to the demands of the modern-day technological-driven work context).

Objectives: The study explored the career agility facets of technological adaptivity, agile learning, and career navigation as potential explanatory mechanisms of individuals' career adaptability.

Method: The study utilised a cross-sectional research design which involved a convenience sample $(N=177)$ of employees (mean age $=34$ years; $\mathrm{SD}=10.14)$ from various industries on managerial $(39 \%)$, staff $(38 \%)$, and professional consultant $(23 \%)$ level positions across the globe. The sample was mostly represented by individuals employed in the South African organisational context $(72 \%)$.

Results: Multiple regression analyses revealed that technological adaptivity, agile learning and career navigation function as facets of adaptive readiness that explain higher levels of the career adaptability resources embedded in individuals' career concern, career control, career curiosity, and career confidence.

Conclusion: The findings contribute new insights into the construct of career agility and extends research on antecedents of career adaptability. Modern-day career counselling practice may find the results useful in helping clients be nimble in their adaptation to the changing career and job conditions of the digital era.

Keywords: adaptivity; adaptive readiness; career adaptability; career agility; technological adaptivity; agile learning; career navigation; broaden-and-build theory.

\section{Background}

Employees' career adaptability is an important self-regulative personal resource that aids in the proactive adaptation to changing work situations. Modern-day work conditions involve, inter alia, more frequent transitions between jobs, organisations, and occupations which require enhanced career adaptation capabilities (Rudolph, Lavigne, Katz, \& Zacher, 2017). The capacity to adjust and display adaptability has become desirable to deal nimbly with the digital era's unprecedented economic and technological forces that are reshaping work opportunities and conditions (Johnston, 2018; Lent, 2018). Career adaptability reflects four transactional psychosocial strengths or capacities (i.e. career concern, career control, career curiosity, and career confidence) that function as career self-management resources in the adaptation process. These resources facilitate successful alignment with, and proactive adaptation to shifting environmental conditions (Hirschi, Herrmann, \& Keller, 2015; Rudolph et al., 2017). Adapting responses, enabled by individuals' career adaptability, is reflected in proactive career behaviours such as, career planning and decision-making. Proactive career behaviours generally lead to positive outcomes such as career satisfaction, life satisfaction, and job satisfaction (Johnston, 2018; Rudolph et al., 2017).

Career agility has emerged as an important construct in popular media to assess individuals' adaptive readiness or willingness to adapt and proactively respond to change (Konstant, 2020; UBC, 2020). The career construction theory (Savickas, 2013) postulates that adaptation starts with adaptive readiness, moves to the use of adaptability resources, then to adapting responses which result in outcomes of adaptation. The extant research on antecedents of career adaptability 
explored career optimism, future work self, learning goal orientation, goal pursuit and personality traits in the form of core self-evaluations and proactivity as indicators of adaptive readiness (Hirschi et al., 2015; Johnston, 2018). However, more empirical insight is needed regarding the manner in which facets of career agility (as indicators of adaptive readiness) explain the activation of career adaptability. Research (see, for example, Hirschi et al., 2015; Johnston, 2018; Perera \& McIlveen, 2017) indicates adaptive readiness as an important antecedent of individuals' career adaptability. Adaptive readiness appears to activate the self-regulated career management resources of career adaptability. These resources were shown to help employees proactively respond to the demands of the modern-day technological-driven work context (Savickas \& Porfeli, 2012). Career agility denotes the willingness or adaptive readiness to proactively adapt to technological change and to engage in continuous learning which may help to trigger the use of careeradaptability resources.

\section{Research objective}

The aim of this research is to explore career agility as a potential antecedent or explanatory mechanism of individuals' career adaptability. Popular media (Andersen, 2020; Konstant, 2020; UBC, 2020) have started to discuss the importance of career agility in career self-management. However, empirical studies on the construct are lacking. To our knowledge, the present study is the first empirical study that provides more insight into the construct of career agility and its link with the well-researched construct of career adaptability. It is postulated that the adaptive readiness to change, reflected in the three facets of career agility (i.e. technological adaptivity, agile learning, career navigation), positively explain individuals' adaptability resources of career concern, career control, career curiosity and career confidence.

\section{Career agility}

In the career development and employment space, career agility refers to the adaptive readiness or willingness to adapt to, and proactively respond to changes that influence one's future career wellbeing and satisfaction (Konstant, 2020; UBC, 2020). The capacity for career agility is deemed important in the context of the Fourth Industrial Revolution (Andersen, 2020; Konstant, 2020). Industry 4.0 is argued to bring new occupations, new industries and fundamentally new ways of work because of technological innovation (Hirschi, 2018). Coetzee, Ferreira and Potgieter (2020) identified three facets of career agility (i.e. technological adaptivity, agile learning, and career navigation) that describe individuals' adaptive readiness for proactive career selfmanagement in the technological-driven digital era. These three facets stemmed from a comprehensive review of the research literature on career adaptive behaviours (which informed the development of the career agility scale), and a preliminary exploratory factor analysis on a South Africanbased pilot study (Coetzee et al., 2020):
- Technological adaptivity denotes a sense of optimism and positive affect toward accelerated technological development and the possibility of new and exciting job and career opportunities these bring. Generally, such individuals feel that technologically evolving job roles optimise their creativity, growth and happiness. They generally seem eager to search for job roles that evolve with the changing technological conditions because of the growth opportunities these offer. Individuals who display high levels of technological adaptivity generally deem it important to update their knowledge and skills in order to capitalise on the new job opportunities created by technological developments. They are confident in marketing their unique brand of values and portfolio of skills across digital networks (Coetzee et al., 2020). Popular media suggest that career agility is built on the coordination of personal strengths and resources that can be leveraged for career success. Creating a diverse network of professional relationships often help to create meaningful new career pathways in uncertain, changing contexts (Andersen, 2020; Konstant, 2020).

- Agile learning alludes to the willingness to set and manage the achievement of career goals. Individuals who display high levels of agile learning generally feel alive and full of energy; they are eager to search for opportunities to learn new skills that will improve their career and job success (Coetzee et al., 2020). Popular media regards the investment in learning as an important facet of career self-management which helps people to acquire an intelligent know-how that accelerates their career development. An agile learning mindset encourages people to consider projects and opportunities that build, leverage and maximise their knowledge, skills and style preferences (Andersen, 2020; Konstant, 2020).

- Career navigation reflects individuals' willingness to navigate and adapt to change and uncertainty in their job and career environment. Individuals with high levels of career navigation are willing to scan the environment for new career opportunities and to take advantage of changes in the job and career environment. Such individuals are highly flexible in their capacity to adapt to change (Coetzee et al., 2020). Andersen (2020) regards career navigation as an important mindset to remain informed of changes and opportunities in the market. Career navigation fosters environmental awareness which helps individuals leverage and apply changes with confidence to their own careers and jobs.

The three facets of career agility denote positive affective states which function as internal adaptivity signals to approach or continue in the advent of technological change. The career construction theory posits in this regard that adaptivity fosters the development and activation of adaptability resources that facilitate the approach to the adaptation process (Perera \& McIlveen, 2017; Savickas, 2013). The broaden-and-build theory (Frederickson, 2004) explains that individuals have the capacity for broadening their mindsets which carry the indirect and long-term adaptive 
benefit of facilitating the building of enduring psychosocial resources for adaptation purposes. Theoretically, it is argued that the facets of career agility function as motivational energisers of adaptivity that promote the building of personal resources needed to achieve career goals.

The broaden-and-build theory (Frederickson, 2004) posits that experiences of positive emotions prompt engagement with the environment and the intrinsic motivational drive to actively partake in activities that may often be adaptive for the individual in an evolutionary sense. The positive affective states embedded in adaptive readiness provide the offset to willingly exhibit the adaptive bias to approach and explore novel objects, people or situations (Frederickson, 2004). Research shows that individuals with high adaptability profiles generally demonstrate high levels of adaptivity, that is, flexibility, willingness and readiness to change (Hirschi \& Valero, 2015; Perera \& McIlveen, 2017). Generally, popular media argue that the positive affective states inherent to career agility enhance individuals' career fitness and motivation to succeed (Andersen, 2020). In this regard, popular media further suggest that the capacity for career agility increases motivation, confidence and resilience. Individuals with high levels of career agility seem more confident in their career decision-making; they are eager to develop career action plans, develop new perspectives on the job search process, and are able to identify a wide range of professional options and possibilities that they are eager to pursue (Konstant, 2020; UBC, 2020). It therefore stands to reason that the dispositional flexibility and positivity inherent to the three facets of career agility may function as formative adaptive readiness contributors to the process of adaptation by activating the drive to use career adaptability resources.

\section{Career adaptability}

Career adaptability involves a set of four psychosocial career self-management resources (i.e. career concern, career control, career curiosity, career confidence) that help individuals adapt to changes in the job market and job conditions (Ginevra, Pallini Vecchio, Nota, \& Soresi, 2016; Savickas \& Porfeli, 2012). Career adaptability and its set of resources are deemed important for people's interaction with the world of work (Johnston, 2018). McMahon, Watson and Brimrose (2012) found that the four career adaptability resources emerge in the evaluation of the career self in relation to external circumstances and internal subjective experiences of the world of work.

Career concern reflects career-related forethought and preparation to respond to the demands, challenges and changes of the future work environment. Career control refers to the degree of responsibility that an individual assumes for their vocational future; it further implies the use of selfregulation strategies to adjust to the needs of different settings. Career curiosity implies the intrinsic motivation to explore possible future selves and associated vocational prospects and options. Career confidence relates to the belief in one's ability to attain career goals; one feels confident to stand by one's own aspirations and goals despite difficulties (Ginevra et al., 2016; Rudolph et al., 2017). These four career adaptability resources appear to be activated by a predisposition to positively and proactively approach new stimuli (Savickas, 2013; Savickas \& Porfeli, 2012).

Adaptive-ready individuals generally report significantly higher levels of career adaptability than those who are more rigid toward change (Perera \& McIlveen, 2017). Research shows that positive emotional dispositions, career concerns, learning orientation and hope do predict adaptability (Johnston, 2018). It therefore stands to reason that the career agility facets of technological adaptivity, agile learning and career navigation will positively predict the activation of individuals' career adaptability, embedded in the resources of career concern, career control, career curiosity and career confidence. Whereas career agility denotes adaptive readiness and a dispositional willingness to adapt and change, the activation of the career adaptability resources actually connects them to the environment (see Hirschi et al., 2015). Taking theory and empirical research together, we formulated the following research hypothesis:

H1: Scores on facets of career agility positively predict scores on facets of career adaptability.

\section{Method \\ Participants}

The sample involved a cross-sectional, convenience sample $(N=177)$ of adult workers (mean age $=34$ years; $\mathrm{SD}=10.14)$ employed in various industries in managerial (39\%), staff (38\%), and professional consultant (23\%) level positions across the globe (South Africa: 72\%; Western Europe: 12\%; Eastern Europe: 6\%; Africa: 6\%; Australia/New Zealand: 2\%; USA: $2 \%$ ). In terms of ethnic origin, white/Caucasian people represented $67 \%$ of the sample. People from African origin comprised $18 \%$ of the sample. The sample was also represented by people from Asian origin (5\%) and of mixed race $(3 \%)$ origin. Male participants represented $46 \%$ and females $54 \%$ of the sample.

\section{Measuring instruments}

\section{Career agility}

The career agility scale developed by Coetzee et al. (2020) was used to measure the following three constructs of career agility: technological adaptivity (seven items; e.g. 'I search for job roles that evolve with changing technological conditions because they offer opportunities for growth and creativity'); agile learning (five items; e.g. 'I continually search for opportunities to learn new skills that will improve my career and job success'); and career navigation (six items; e.g. 'I am able to navigate and adapt to change and uncertainty in my job and career environment'). Respondents rated each item on a seven-point Likert-type scale ( 1 = strongly disagree; 7 = strongly agree). Preliminary research indicated construct validity and high internal consistency reliability $(\alpha=0.90)$ on 
the career agility scale. The internal consistency reliability for the subscales ranged between 0.73 and 0.89 (Coetzee et al., 2020).

\section{Career adaptability}

The well-established career adapt-ability scale of Savickas and Porfeli (2012) was applied to measure respondents' overall career adaptability and their career concern (six items; e.g. 'Thinking about what my future will be like') ; career control (six items; e.g. 'Keeping up to date with the latest developments in my occupational field'), career curiosity (six items; e.g. 'Becoming curious about new opportunities'), and career confidence (five items: e.g. 'Working up to my ability'). Respondents rate each item on a seven-point Likert-type scale ( 1 = strongly disagree; 7 = strongly agree). The career adapt-ability scale has proven construct validity and internal consistency reliability (Savickas \& Porfeli, 2012; Uy, Chan, Sam, Ho, \& Chernyshenko, 2015).

\section{Procedure}

Data were collected via the professional, online social media platform, namely LinkedIn. The invitation to participate in the study targeted $(N=1000)$ individuals with an electronic link to the questionnaire. A total of $(n=177)$ usable questionnaires were returned and thus a response rate of $18 \%$ was achieved. The participants received an electronic link via email. Responses were captured on an Excel spreadsheet and converted into an SPSS file for data analysis purposes.

\section{Ethical consideration}

Ethical clearance and permission to conduct the research were obtained from the management of the University of South Africa (Ethics certificate reference: ERC Ref\#: 2019 CEMS/IOP_010). The participants were invited to voluntarily engage in the research study. The online questionnaire included an informed consent form. The privacy, anonymity and confidentiality of all the participants were ensured and honoured. The participants gave informed consent that the data could be used for research purposes.

\section{Data analysis}

Descriptive statistics, bivariate correlations and multiple regression analysis were performed by using SAS/STAT ${ }^{\circledR}$ software version $9.4 \mathrm{M} 5^{\odot}(2017)$. Tolerance $(<0.1)$ and the variance inflation factor (VIF above 2.5) were utilised to assess any concerns about multicollinearity. Results were interpreted at the $95 \%$ confidence level interval.

\section{Results}

Table 1 shows that the internal consistency reliability coefficients for all the constructs were acceptable $(\geq 0.75$ to $\leq 0.92)$. The correlations between the three career agility constructs and the career adaptability constructs were all positive and significant $(r \geq 0.39$ to $r \leq 0.59 ; p=0.0001$; moderate to large practical effect).

As shown in Table 2, all five the ANOVA models were significant: Model 1 (career adaptability): $F=16.34 ; p=0.0001$; $R^{2}=0.43$ (large practical effect); model 2 (career concern): $F=8.28 ; p=0.0001 ; R^{2}=0.30$ (large practical effect); model 3 (career control): $F=12.91 ; p=0.0001 ; R^{2}=0.37$ (large practical effect); model 4 (career curiosity): $F=15.54 ; p=0.0001 ; R^{2}=0.41$ (large practical effect); model 5 (career confidence): $F=9.75$; $p=0.0001 ; R^{2}=0.30$ (large practical effect). The tolerance values for all the models were greater than 0.20 and the VIF values were lower than 0.20, which showed that multicollinearity was not a threat to the findings.

Table 2 shows that the three career agility constructs (technological adaptivity, agile learning and career navigation) were all statistically significant positive predictors and explained a large amount of the variance in overall career adaptability, career control, career curiosity, and career confidence.

Career navigation was a statistically significant predictor of overall career adaptability $(\beta=0.29 ; p=0.001)$, career control $(\beta=0.28 ; p=0.01)$, career curiosity $(\beta=0.31 ; p=0.001)$ and career confidence $(\beta=0.25 ; p=0.01)$.

Technological adaptivity was a statistically significant predictor of overall career adaptability $(\beta=0.28 ; p=0.001)$, career control $(\beta=0.25 ; p=0.01)$, career curiosity $(\beta=0.23$; $p £ 0.01)$ and career confidence $(\beta=0.24 ; p=0.01)$.

Agile learning was a statistically significant predictor of overall career adaptability $(\beta=0.24 ; p=0.001)$, career control $(\beta=0.18 ; p=0.05)$, career curiosity $(\beta=0.26 ; p=0.001)$ and career confidence $(\beta=0.20 ; p=0.01)$.

\begin{tabular}{|c|c|c|c|c|c|c|c|c|c|c|c|c|c|}
\hline Number & Variable & Mean & SD & $\alpha$ & CR & 1 & 2 & 3 & 4 & 5 & 6 & 7 & 8 \\
\hline 1 & Technological adaptivity & 5.34 & 1.06 & 0.89 & 0.90 & - & - & - & - & - & - & - & - \\
\hline 2 & Agile learning & 5.62 & 1.12 & 0.75 & 0.79 & 0.45 & - & - & - & - & - & - & - \\
\hline 3 & Career navigation & 5.38 & 1.10 & 0.80 & 0.81 & 0.67 & 0.45 & - & - & - & - & - & - \\
\hline 4 & Career adaptability & 6.08 & 0.75 & 0.95 & 0.95 & 0.59 & 0.49 & 0.59 & - & - & - & - & - \\
\hline 5 & Career concern & 6.07 & 0.85 & 0.86 & 0.86 & 0.45 & 0.39 & 0.46 & 0.81 & - & - & - & - \\
\hline 6 & Career control & 6.03 & 0.85 & 0.84 & 0.83 & 0.53 & 0.41 & 0.50 & 0.89 & 0.61 & - & - & - \\
\hline 7 & Career curiosity & 6.03 & 0.92 & 0.90 & 0.90 & 0.57 & 0.50 & 0.58 & 0.91 & 0.67 & 0.76 & - & - \\
\hline 8 & Career confidence & 6.20 & 0.82 & 0.92 & 0.92 & 0.50 & 0.41 & 0.50 & 0.87 & 0.55 & 0.73 & 0.74 & - \\
\hline
\end{tabular}

$*, p=0.0001$

SD, Standard deviation; $\alpha$, Cronbach alpha coefficient; CR, Composite reliability. 
TABLE 2: Results of multiple regression analysis $(N=177)$.

\begin{tabular}{|c|c|c|c|c|c|c|c|}
\hline \multirow[t]{2}{*}{ Variable } & \multicolumn{3}{|c|}{$\beta$} & \multirow[t]{2}{*}{ SE } & \multirow[t]{2}{*}{$t$} & \multicolumn{2}{|c|}{ Model info } \\
\hline & $\begin{array}{c}\text { Standardised } \\
\boldsymbol{\beta}\end{array}$ & $\begin{array}{c}\text { Unstandardised } \\
\boldsymbol{\beta}\end{array}$ & $\mathrm{Cl} 95 \%$ (lower; upper) & & & $F p$ & Adjusted $R^{2}$ \\
\hline Career adaptability & - & - & - & - & - & $16.34 * * *$ & 0.43 \\
\hline Technological adaptivity & 0.28 & 0.20 & $0.08 ; 0.31$ & 0.06 & $3.42 * * *$ & - & - \\
\hline Agile learning & 0.24 & 0.16 & $0.06 ; 0.25$ & 0.05 & $3.39 * * *$ & - & - \\
\hline Career navigation & 0.29 & 0.20 & $0.09 ; 0.31$ & 0.06 & $3.49 * * *$ & - & - \\
\hline Career concern & - & - & - & - & - & $8.28 * * *$ & 0.30 \\
\hline Technological adaptivity & 0.26 & 0.21 & $0.06 ; 0.36$ & 0.08 & $2.71 * *$ & - & - \\
\hline Agile learning & 0.18 & 0.14 & $0.02 ; 0.26$ & 0.06 & $2.30 *$ & - & - \\
\hline Career navigation & 0.16 & 0.13 & $-0.02 ; 0.27$ & 0.07 & 1.74 & - & - \\
\hline Career control & - & - & - & - & - & $12.91 * * *$ & 0.37 \\
\hline Technological adaptivity & 0.37 & 0.20 & $0.07 ; 0.34$ & 0.07 & $2.92 * *$ & - & - \\
\hline Agile learning & 0.18 & 0.14 & $0.03 ; 0.25$ & 0.06 & $2.47^{*}$ & - & - \\
\hline Career navigation & 0.28 & 0.22 & $0.08 ; 0.35$ & 0.07 & $3.23 * *$ & - & - \\
\hline Technological adaptivity & 0.41 & 0.20 & $0.06 ; 0.34$ & 0.07 & $2.75^{* *}$ & - & - \\
\hline Agile learning & 0.26 & 0.21 & $0.09 ; 0.32$ & 0.06 & $3.62 * * *$ & - & - \\
\hline Career navigation & 0.31 & 0.26 & $0.12 ; 0.40$ & 0.07 & $3.69 * * *$ & - & - \\
\hline Career confidence & - & - & - & - & - & $9.75 * * *$ & 0.30 \\
\hline Technological adaptivity & 0.24 & 0.19 & $0.05 ; 0.33$ & 0.07 & $2.66 * *$ & - & - \\
\hline Agile learning & 0.20 & 0.14 & $0.03 ; 0.25$ & 0.06 & $2.55^{* *}$ & - & - \\
\hline Career navigation & 0.25 & 0.18 & $0.05 ; 0.32$ & 0.07 & $2.66 * *$ & - & - \\
\hline
\end{tabular}

$*, p \leq 0.05 ; * *, p \leq 0.01 ; * * *, p \leq 0.001$.

$\beta$, standardised estimate; $\mathrm{Cl}$, confidence interval; $\mathrm{SE}$, standard error.

Technological adaptivity $(\beta=0.26 ; p=0.01)$, and agile learning $(\beta=0.18 ; p=0.05)$ were also both statistically significant predictors of career concern.

The results provided supportive evidence for our research hypothesis H1: Scores on facets of career agility positively predict scores on facets of career adaptability.

\section{Discussion}

The present study explored career agility as an antecedent of career adaptability. The results confirmed our hypothesis that the three facets of career agility, namely technological adaptivity, agile learning, and career navigation would positively predict individuals' career adaptability. It was evident that the facets of career agility explained individuals' cognitive awareness of the career self-management resources inherent to their career adaptability.

The findings corroborate Savickas's (2013) view that the four resources of career adaptability (i.e. career concern, career curiosity, career control, and career confidence) are activated by individuals' adaptive readiness. Generally, our findings highlighted technological adaptivity, career navigation and agile learning as important facets of adaptive readiness that seem to positively activate the resources of career adaptability. Technological adaptivity implies a cognitive openness and positive affective state toward technological change. Agile learning denotes an eagerness to expand one's skills and knowledge through new job and career opportunities. Career navigation reflects the willingness to proactively navigate and adapt to change
(Coetzee et al., 2020). It appears from the findings that the sense of optimism and positive affect toward accelerated technological development, as well as the energy and positive affect underpinning agile learning, activated the career adaptability resources needed for proactive career planning (concern), career decidedness (control), career exploration (curiosity) and career self-efficacy beliefs (confidence). The findings are in agreement with research showing that positive emotional dispositions and learning orientation positively predict adaptability (Johnston, 2018). The strong explanatory power of especially technological adaptivity and career navigation regarding all the career adaptability resources could be attributed to the basic premise of the broaden-and-build theory (Frederickson, 2004) that positively affect generally broadens individuals' thought-action repertoires or mindsets, and calls forth specific personal resources and strengths that facilitate adaptation to changing and challenging circumstances (Frederickson \& Branigan, 2005).

The willingness to scan the environment and adapt to career changes (career navigation) was especially relevant to activating the resources of career control (i.e. taking responsibility for one's future and keeping up to date with new developments in their occupational field), career curiosity (i.e. displaying the intrinsic motivation to explore alternative futures and actions that may lead to new futures), and career confidence (i.e. belief in one's ability to attain their career goals and overcome obstacles). The findings support previous research showing that highly career-adaptive ready individuals characteristically display important proactive career self-management capabilities, such as those embedded 
in their career adaptability resources (see Johnston, 2018; Rudolph et al., 2017; Savickas \& Porfeli, 2012).

The study findings have noteworthy implications for theory and practice. The study extends current theory on the antecedents of career adaptability by its exploration of the construct of career agility. Drawing from the reasoning of Johnston (2018), the career agility facets denote individuals' adaptive readiness (i.e. willingness to change and adapt), which, in turn, seemingly triggers the intrinsic motivation to draw on career adaptability resources (i.e. self-regulated career management strengths and capabilities) to deal nimbly with current and anticipated changes in the Industry 4.0 employment environment. Popular media argue that people with high levels of career agility are resourceful in identifying and pursuing professional options and possibilities; they succeed in the job search process, and are able to design careers that are meaningful and fulfilling (Andersen, 2020; UBC, 2020). The present study's findings empirically corroborate arguments made by popular media that individuals' capacity for career agility increases their motivation and confidence, and helps them to be more confident in their decision-making and develop better career action plans (UBC, 2020).

The findings may be used to inform contemporary career counselling practice concerned with raising individuals' career self-management capability and adaptive career response-ability. An initial assessment of clients' career agility may prove useful in evaluating their cognitive openness and positive affective state toward technological change, their eagerness to engage in learning new skills, and to navigate the career environment of Industry 4.0 for new opportunities to craft meaningful professional lives. An assessment of career agility may help trigger the use of career adaptability resources which are essential for proactive career self-management and successful career outcomes.

\section{Research limitations and directions for future research}

Our study employed cross-sectional data to test the research hypothesis. No causal claims can therefore be made. The research design was appropriate for the exploratory nature of the research, because little is known about the link between the three career agility and the career adaptability constructs. Future research should replicate the study and include a wider range of career constructs in order to assess the construct and predictive validity of the career agility scale. Longitudinal designs and intervention studies could be conducted to test whether training individuals to be more career agile can, in turn, raise career adaptability and contribute to career satisfaction across the lifespan. The sample also scored very high on all the career agility scale constructs; there was also little variability on the career adaptability scale scores. The mean scores could have been attributed to the sample being predominantly recruited from a professional social media platform. Future research should replicate the study in more diverse samples from various job levels and occupational groups.

\section{Conclusion}

The study contributed to research on the relatively new construct of career agility. The study showed that the positive affect and career-related thought-action repertoires embedded in the construct of career agility positively explained the use of career self-management resources inherent to individuals' career adaptability. The study advances research on antecedents of career adaptability and the findings can help inform modern-day career counselling.

\section{Acknowledgements}

All authors contributed to the data collection. M.C. assisted with the data analysis and interpretation. All authors contributed to the conceptual framework and writing up of the research article.

\section{Competing interests}

The authors have declared that no competing interest exist.

\section{Authors' contributions}

All authors contributed equally to this work.

\section{Funding information}

This research received no specific grant from any funding agency in the public, commercial, or not-for-profit sectors.

\section{Data availability statement}

Data sharing is not applicable to this article as no new data were created or analysed in this study.

\section{Disclaimer}

The views and opinions expressed in this article are those of the authors and do not necessarily reflect the official policy or position of any affiliated agency of the authors.

\section{References}

Andersen, M. (2020). Career agility for competitive advantage. Andersen. Retrieved from http://www.margotandersen.com/career-agility-competitive-advantage/

Coetzee, M., Ferreira, N., \& Potgieter, I.L. (2020). Career Agility Scale: Preliminary Research Report. Unpublished Research Report, Department of Industrial and Organisational Psychology, University of South Africa, Pretoria, South Africa.

Frederickson, B.L. (2004). The broaden-and-build theory of positive emotions Philosophical transactions of the Royal Society B: Biological Sciences, 359(1449), 1367-1377. https://doi.org/10.1098/rstb.2004.1512

Frederickson, B.L., \& Branigan, C. (2005). Positive emotions broaden the scope of attention and thought-action repertoires. Cognition and emotion, 19(3), 313-332, https://doi.org/10.1080/02699930441000238

Ginevra, M.C., Pallini, S., Vecchio, G.M., Nota, L., \& Soresi, S. (2016). Future orientation and attitudes mediate career adaptability and decidedness. Journal of Vocationa Behavior, 96, 102-110. https://doi.org/10.1016/j.jvb.2016.08.003

Hirschi, A. (2018). The fourth industrial revolution: Issues and implications for career research and practice. The Career Development Quarterly, 66(3), 192-204. https:// doi.org/10.1002/cdq.12142

Hirschi, A., Herrmann, A., \& Keller, A.C. (2015). Career adaptivity, adaptability and adapting: A conceptual and empirical investigation. Journal of Vocational Behavior, 87, 1-10. https://doi.org/10.1016/j.jvb.2014.11.008 
Hirschi, A., \& Valero, D. (2015). Career adaptability profiles and their relationship to adaptivity and adapting. Journal of Vocational Behavior, 88, 220-229. https://doi. org/10.1016/j.jvb.2015.03.010

Johnston, C.S. (2018). A systematic review of the career adaptability literature and future outlook. Journal of Career Assessment, 26(1), 3-30. https://doi. org/10.1177/1069072716679921

Lent, R.W. (2018). Future of work in the digital world: Preparing for instability and opportunity. The Career Development Quarterly, 66(3), 205-219. https://doi. org/10.1002/cdq.12143

Konstant, M. (2020). Career agility for the future of your work. Networlding. Retrieved from https://networlding.com/career-agility-for-the-future-of-your-work/

McMahon, M., Watson, M., \& Brimrose, J. (2012). Career adaptability: A qualitative understanding from the stories of older women. Journal of Vocational Behavior 80(3), 762-768. https://doi.org/10.1016/j.jvb.2012.01.016

Perera, H.N., \& Mcllveen, P. (2017). Profiles of career adaptivity and their relation with adaptability: Adapting and adaptation. Journal of Vocational Behavior, 98, 70-84. https://doi.org/10.1016/j.jvb.2016.10.001
Rudolph, C.W., Lavigne, K.N., Katz, I.M., \& Zacher, H. (2017). Linking dimensions of career adaptability to adaptation results. Journal of Vocational Behavior, 102, 151-173. https://doi.org/10.1016/j.jvb.2017.06.003

SAS version 9.4M5@ (2017). SAS/STAT ${ }^{\circledR}$ software. Cary, NC: SAS Institute Inc.

Savickas, M.L. (2013). Career construction theory and practice. In S.D. Brown \& R.W. Lent (Eds.), Career development and counselling: Putting theory and research to work (pp. 42-70). Hoboken, NJ: Wiley Publishing.

Savickas, M.L., \& Porfeli, E.J. (2012). Career Adapt-Abilities Scale: Construction, reliability and measurement equivalence across 13 countries. Journal of Vocational Behavior, 80(3), 661-673. http://dx.doi.org/10.1016/j.jvb.2012.01.011

UBC. (2020). What is career agility and why do you need it? Alumni UBC. Retrieved from https://www.alumni.ubc.ca/2017/blog/careers-blog/career-agility-need/

Uy, M.A., Chan, K., Sam, Y.L., Ho, M.R., \& Chernyshenko, O.S. (2015). Proactivity, adaptability and boundaryless career attitudes: The mediating role of entrepreneurial alertness. Journal of Vocational Behavior, 86, 115-123. https:// doi.org/10.1016/j.jvb.2014.11.005 